\title{
META BOLIC PROFILE OF THE BLOOD PLASMA OF ADULT MALE NUTRIAS (Myocastor coypus M.)
}

\author{
P. JELÍNEK, ${ }^{1} \mathrm{~J}$. ILLEK ${ }^{2}$ \\ 1 Department of Cattle, Horse and Sheep Husbandry, Faculty of Agronomy, University \\ of Agriculture, 66265 Brno \\ 2 Department of Diagnosis, Therapy and Prevention of Animal Diseases, \\ University of Veterinary Science, 61242 Brno
}

Received April 6, 1983

\begin{abstract}
Jelínek P., J. Illek: Metabolic Profile of the Blood Plasma of Adult Male Nutrias (Myocastor coypus M.). Acta Vet. Brno, 53, 1984: 49-55.

The values of basic biochemical data (total protein, percent portion of albumin, alpha, beta and gamma globulin, urea, AST and ALT activities, alkaline phosphatase, glucose concentration, total calcium, inorganic phosphorus, magnesium, manganese, zinc and copper) determined in the blood plasma of 22 adult clinically healthy male nutrias during the summer season are given. The blood for analysis was obtained by heart puncture.
\end{abstract}

Nutria, blood, protein urea, glucose, $A S T, A L T$, minerals.

The application of new approaches in nutria nutrition and husbandry requires a more detailed study of basic physiological processes in these animals. Whereas in cattle, pigs and sheep problems have been studied in detail (Kolb and Gürtler 1971; Underwood 1971; Henniget al. 1972; Wiesner 1972; Illek and Jagoš 1977; Illek 1979; Jagoš 1980) in fur animals, especially in nutria, the data on blood and blood plasma composition are incomplete.

The macro- and microelement concentration in the blood of eight months old nutria males and females was studied by Krchñavý (1977). The blood samples were collected from nasal openings on killing the animals. Partial hematological and biochemical blood parameters in nutrias were reported by Wenzel $(1974,1982)$ and Konrád (1983).

The dynamics of changes in hematological and biochemical indices during ontogenesis of male nutrias was studied by Jelínek, Glásrová (1982a, b), Jelínek, Pícha, Píchová (1981), Jelínek, Píchová, Pícha (1981). The concentrations of some microelements in blood plasma, liver, hair, gonads and accessory glands of adult male nutrias were determined by Jelínek, Illek and Jagoš (1982).

The aim of this work was to determine the total content of protein and immunoglobulins, the proportion of albumin, alpha, beta and gamma globulins, the urea content, the AST, ALT and alkaline phosphatase activity, the concentration of glucose, total calcium, inorganic phosporus, magnesium, manganese, zinc and copper in the blood plasma of clinically healthy male nutrias.

\section{Material and Methods}

For the biochemical analysis of blood plasma blood samples obtained by heart puncture of 22 adult male nutrias were used. Further characteristics of the animals examined are presented in another paper (Jelínek 1983).

The determination of basic biochemical parameters was carried out in the following way: the total protein of blood plasma was determined using the Bio-Test (Lachema), while the immunoglobulin content was established turbidimetrically by the zinc-sulphate reaction using the Bio-Test 
(Lachema). The portion of albumin, alpha globulin and also of beta and gamma globulins was defined by microelectrophoresis and the evaluation was carried out on the Densiscan automatic densitometer. The levels of alkaline phosphatase, AST and ALT, urea and inorganic phosphorus were determined photometrically using the Bio-Test kit (Lachema). The concentration of Ca, $\mathrm{Mg}, \mathrm{Na}, \mathrm{K}, \mathrm{K}, \mathrm{Zn}$ and $\mathrm{Cu}$ was determined by the atomic absorption spectrophotometry (AAS) on the Hilger Atomspek. The standard solutions for AAS produced by Harleco were used for the calibration. The level of plasma manganese was defined by the flameless atomic absorption spectrophotometry on the Atomspek H 1551 instrument equipped with the automatic deuterium background corrector. The measurement was effected directly without applying the integration.

\section{Results}

The summarized characteristics of the followed biochemical parameters of blood plasma of male nutrias are presented in Table 1.

The total protein levels in blood plasma were found to be within the range of $53.20-69.90 \mathrm{~g} / 1$. The average value, as follows from the table, was $61.24 \mathrm{~g} / 1$. The relatively narrow span between minimal and maximal concentration of the total protein is reflected also by the variability level evaluated by the coefficient of variation $\mathrm{v}=7.90 \%$

Table 1

Summarized characteristics of biochemical parameters of the blood plasma

\begin{tabular}{|c|c|c|c|c|}
\hline Parameter & $\bar{x}$ & $\boldsymbol{s}$ & $S \bar{x}$ & $v$ \\
\hline $\begin{array}{l}\text { Total protein }(\mathrm{g} / \mathrm{l}) \\
\text { Albumin } \mathrm{g} / 1 \\
\text { Globulin alpha } \mathrm{g} / \mathrm{l} \\
\text { Globulin beta and gamma } \mathrm{g} / 1 \\
\text { Immunoglobulin } \mathrm{U} \\
\text { Urea mmol/1 } \\
\text { Alkaline phosphatase } \mu \mathrm{kat} / 1 \\
\text { AST } \mu \mathrm{kat} / 1 \\
\text { ALT } \mu \mathrm{kat} / 1 \\
\text { Glucose mmol/1 } \\
\text { Calcium } \mathrm{mmol} / 1 \\
\text { Phosphorus } \mathrm{mmol} / 1 \\
\text { Magnesium } \mathrm{mmol} / 1 \\
\text { Manganese mmol } / 1 \\
\text { Zinc } \mu \text { mol } / 1 \\
\text { Copper } \mu \mathrm{mol} / 1\end{array}$ & $\begin{array}{l}61.24 \\
35.89 \\
8.72 \\
16.52 \\
15.85 \\
7.85 \\
0.114 \\
1.42 \\
0.28 \\
6.96 \\
2.63 \\
2.48 \\
1.35 \\
0.39 \\
34.97 \\
16.92\end{array}$ & $\begin{array}{l}4.8383 \\
4.6908 \\
1.6219 \\
3.6179 \\
6.8177 \\
1.6089 \\
0.0445 \\
0.5205 \\
0.0951 \\
1.2441 \\
0.2370 \\
0.4969 \\
0.1380 \\
0.0951 \\
9.7152 \\
5.8960\end{array}$ & $\begin{array}{l}1.0315 \\
1.0001 \\
0.3458 \\
0.7713 \\
3.4535 \\
0.3430 \\
0.0094 \\
0.1110 \\
0.0203 \\
0.2674 \\
0.0505 \\
0.1059 \\
0.0294 \\
0.0203 \\
2.0203 \\
1.2570\end{array}$ & $\begin{array}{r}7.90 \\
13.07 \\
18.60 \\
21.90 \\
43.01 \\
20.49 \\
38.79 \\
36.65 \\
33.97 \\
18.01 \\
9.01 \\
20.03 \\
10.22 \\
24.38 \\
27.78 \\
34.85\end{array}$ \\
\hline
\end{tabular}

The plasma albumin showed a relatively broader span of individual values: from 23.0 to $42.3 \mathrm{~g} / \mathrm{l}$, the mean being $35.89 \mathrm{~g} / 1$.

The average value of alpha globulin in male nutrias was found to be $8.72 \mathrm{~g} / 1$, the limiting values being 6.06 and $11.75 \mathrm{~g} / \mathrm{l}$.

The content of beta and gamma globulins in the blood plasma of male nutrias ranged from 9.37 to $25.35 \mathrm{~g} / \mathrm{l}$, the variability being rather high ( $\mathrm{v}=21.90 \%$ ). The average value of this parameter was found to be $16.52 \mathrm{~g} / \mathrm{l}$.

The immunoglobulin content in individual animals varied greatly, namely between marginal values $6.84 \mathrm{U}$ and $24.68 \mathrm{U}$, the average value being $15.85 \mathrm{U}$.

The urea concentration in the blood plasma of the followed male nutrias $(\mathbf{n}=$ $=22$ ) ranged from $5.04 \mathrm{mmol} / 1$ to $11.11 \mathrm{mmol} / 1$. From the summarized mathematico-statistical data of the given biochemical parameter it follows that the average urea concentration in the blood plasma was found to be $7.85 \mathrm{mmol} / \mathrm{l}$, the coefficient of variation being $20.50 \%$. 
Activities of alkaline phosphatase in individual male nutrias showed high individual differences. Minimal and maximal concentrations were found to be $0.043 \mu \mathrm{kat} / 1$ and $0.182 \mu \mathrm{kat} / 1$, resp., the average phosphatase activity being $0.114 \mu \mathrm{kat} / 1$. The high individual activities of this enzyme were supported also by a high variability level $(\mathrm{v}=38.80 \%)$.

The average value of aspartate aminotransferase (AST) activity in the blood plasma of the followed animals was $1.42 \mu \mathrm{kat} / \mathrm{l}$. Enzyme activities, out of which the average level was evaluated, were found to be in the range from $0.60 \mu \mathrm{kat} / 1$ to $2.35 \mu \mathrm{kat}$. $/ 1$. The value of the coefficient of variation was $36.65 \%$.

The activity of alanine aminotransferase (ALT), similarly as that of the two former enzymes, showed relatively high individual diferences, the average value being $0.28 \mu \mathrm{kat} / 1$. The variability of ALT concentration in the blood plasma was also high $(\mathrm{v}=33.97 \%)$.

The glucose concentration in the blood plasma of nutrias showed in general a constant level, the average value reaching $6.96 \mathrm{mmol} / 1$. In most cases the individual levels approach the concentrations in man, ranging from $5.14 \mathrm{mmol} / 1$ to $10.08 \mathrm{mmol} / 1$. The variability level was observed to be medium.

The level of total calcium in the followed group of animals was relatively balanced, the concentrations ranging from $2.30 \mathrm{mmol} / 1$ to $3.03 \mathrm{mmol} / 1$ with the mean value of $2.63 \mathrm{mmol} / 1$. The variability was found to be $9.01 \%$.

The average content of inorganic phosphorus in the blood plasma amounted to the $2.48 \mathrm{mmol} / \mathrm{l}$. The values of this parameter ranged from $1.96 \mathrm{mmol} / 1$ to $3.47 \mathrm{mmol} / \mathrm{l}$, the variability being $20.04 \%$.

The levels of plasma magnesium could be regarded as well balanced, the concentration found ranging from $1.04 \mathrm{mmol} / 1$ to $1.60 \mathrm{mmol} / \mathrm{l}$. The mean magnesium content at the average variability amounted to $1.35 \mathrm{mmol} / 1$ of the blood plasma.

The concentrations of plasma manganese showed also a constant level (see Table 1). With the exception of three cases out of the total of 22 male nutrias examined its concentration was measured to be $0.36 \mu \mathrm{mol} / 1$. The table shows the average manganese content of $0.39 \mu \mathrm{mol} / 1$ and the value of $24.38 \%$.

A similar concentration was observed in another microelement - zinc-in the blood plasma of male nutrias. The mean value of $34.97 \mu \mathrm{mol} / 1$ was found, the degree of variability being however higher, $\mathrm{v}=27.78 \%$. The range of plasma zinc concentration was found to be from $24.63 \mu \mathrm{mol} / 1$ to $55.99 \mu \mathrm{mol} / 1$ of the blood plasma.

The last of microelements, determined in the blood plasma of 22 male nutrias, was copper which was found to range from $9.92 \mu \mathrm{mol} / 1$ to $29.56 \mu \mathrm{mol} / 1$. The differences in copper concentrations appeared also in the higher coefficient of variation $\mathrm{v}=34.86 \%$. The average content of this element was found to be 16.92 $\mu \mathrm{mol} / 1$ of the blood plasma.

\section{Discussion}

To date no particular attention has been paid to basic physiological blood values of nutrias. We believe that one of the reasons for this is the lack of a method for blood sample taking for the complex laboratory examination. That is why a method of sampling by heart puncture has been worked out, without previous tranquilization of the animals.

The present results show that the value of total protein in the blood plasma of 
nutrias was in average $61.24 \pm 4.8383 \mathrm{~g} / \mathrm{l}$, over half of the value of total protein being albumins. Only in two cases the albumin content was found to be lower than $50 \%$. Great individual differences were observed in globulin fractions. Jelínek (1980) found in male nutrias of various age the total protein concentration in the blood plasma to range from $54.90 \mathrm{~g} / 1$ to $64.10 \mathrm{~g} / 1$ and a slightly lower variation in albumin and globulin contents. The concentration of total protein and albumins in blood plasma is influenced predominantly by the level of nutrition and functional condition of liver, that of globulins mostly by the immunologic response of the organism.

The concentration of urea, as one of the main final products of protein metabolism, varied in blood plasma from $5.04 \mathrm{mmol} / 1$ to $11.11 \mathrm{mmol} / 1$. The mean value was found to be $7.85 \mathrm{mmol} / 1$. These data correspond to the levels observed in most mammals. Jelínek (1980) reported similar results in growing nutrias, the values ranging from 6.38 to $10.24 \mathrm{mmol} / 1$. It is generally reported that the urea content in blood plasma is dependent on the level of protein nutrition and that it is influenced by the functional condition of liver and kidneys. With deficient protein nutrition the urea content decreases, while at higher protein intake it increases. Very marked increase in the urea content in blood plasma could be observed if the kidneys, due to a disease, lost their ability to excrete urea (Jagoš 1975).

Great individual differences were found also in enzyme activities, especially in alkaline phosphatase and AST. The activity of alkaline phosphatase changes with age of animals. In young animals it is higher than in adults, which is accounted for by the growth of bones and their mineralization (Hořejši et al. 1963). The values of alkaline phosphatase found by Jelínek (1980) in nutrias of various ages ranged from $5.74 \mathrm{U}$ to $35.59 \mathrm{U}$, higher values being observed during growth. The mean activities of alkaline phosphatase found in nutrias are generally lower than those observed in cattle and pigs, being nevertheless very similar to those of sheep, dogs and rabbits (Jagoš 1980). The GPT value in the blood plasma of nutrias ranged from $0.10 \mu \mathrm{mol} / \mathrm{ml}$ to $0.47 \mu \mathrm{mol} / \mathrm{ml}$, the values being lower than those reported for other species (Sova et al. 1976; Jag oš 1980).

The glucose concentration in the blood plasma of nutrias averaged $6.96 \pm$ $\pm 1.2441 \mathrm{mmol} / \mathrm{l}$. The lowest and highest values were found to be $5.14 \mathrm{mmol} / 1$ and $10.08 \mathrm{mmol} / \mathrm{l}$, resp. Glucose is the principal component of energy metabolism and, to a certain extent, reflects the carbohydrate intake level in nutrition. Hyperglycaemia appears also in animals that are in a state of stress (Hořejší et al. 1963). Increased glycaemia in one animal could thus be explained by the stress condition at blood sampling.

The calcium content in the blood plasma of nutrias was relatively balanced. It was found to be $2.63 \pm 0.2370 \mathrm{mmol} / 1$, the coefficient of variation being the lowest of all parameters followed. This finding indicates a relatively good calcium homeostasis in adult nutrias. The average value of calcium content agrees with data reported also for other species (Sova 1979). Similar results in nutrias were observed by Krchňavý (1977). Jelínek (1980) reports the values of plasma calcium in nutrias of various ages reaching in average $2.58 \mathrm{mmol} / 1$.

Inorganic phosphorus concentration in the blood plasma of nutrias exhibited a more pronounced variation than calcium, amounting in average to $2.48 \pm$ $0.4969 \mathrm{mmol} / \mathrm{l}$. This value is almost identical with that reported by Jelinek (1980). Phosphorus in mammalian organism plays a multifunctional role. The content of inorganic phosphorus in blood plasma changes during the ontogenesis, young animals having higher concentrations than adults. It changes in the de- 
pendence on phosphorus intake, on acid-base balance of internal environment and also on the level of mineralization and demineralization processes in bones. These factors may have influenced also the content of inorganic phosphorus in the blood plasma of nutrias.

Magnesium, being mostly an intracellular cation, is contained only in a small amount in blood plasma. The average value was found to be $1.35 \pm 0.1380 \mathrm{mmol} / 1$, the variability of individual values being, similarly to the case of calcium, low. The mean value of plasma magnesium was within the range reported by Jelinek (1980) for nutrias of various ages. Similar results wereobserved also by Krchňavý (1977) who, however, demonstrated significantly higher content of plasma magnesium in nutria males than in females.

Available literature data concerning the content of manganese, zinc and copper in biological fluids and tissues of nutrias are very scarce. While there is abundance of literature data on reproduction disturbances in zinc, manganese and copper deficiencies concerning usual farm animals and carnivores (Underwood 1971; Illek 1979; Kolb and Gürtler 1971, Hennig 1972; Wiesner 1972; Wenzell 1974), the surveys on nutrias are sporadic. Manganese has been studied lately mainly in connection with the bone metabolism and with reproduction processes. The manganese content in blood plasma is very low and corresponds to the values determined for other animal species (Kolg and Gürtler 1972; Hennig 1972; Illek and Jagoš 1977). Already Boyer et al. (1942), S mith (1944 - in: Underwood 1977) reported on the occurrence of sterility and lack of libido in male rats and rabbits suffering from manganese deficiency. Also Wenzel (1974) describes marked reproduction disturbances in carnivorous fur animals of both sexes when the intake of manganese in the feed ration is not sufficient. Apart from the detrimental influence on all fertility parameters, a strong shift of the natural ratio of sexes is observed towards males at manganese deficiency (Wiesner 1972). The occurrence of fertility disturbances in some of our nutria farms, and inadequate libido of male nutrias requires a more detailed study also from the manganese deficiency point of view.

The zinc content in the blood plasma was found to be approximately 90 times higher than that of manganese and to amount in average to $34.97 \pm 9.71 \mu \mathrm{mol} / 1$. Individual differences were great and the coefficient of variation reached the value of $27.78 \%$. Similar results were reported also by Jelínek (1980). The determined zinc content in the blood plasma of nutrias is in average higher than that of zinc in the blood plasma of cattle and pigs, fitting, however, into the range reported for the mentioned species. A more detailed study is needed for the observed influence of zinc upon skin and hair; this is particularly important from the viewpoint of the nutria skin and hair quality. Also the finding that the zinc content in the body of adult mammals is higher than that in young animals is of interest (Veliký 1964). Jelínek (1980) has also confirmed this observation by finding a lower zinc concentration in the blood plasma of young as compared to adult nutrias. Krchñavý (1977) determined the zinc content in the blood plasma and found it to be in a very broad range, i. e. from $122 \mu \mathrm{g} / 100 \mathrm{ml}$ to $490 \mu \mathrm{g} / 100 \mathrm{ml}$. This author observed no sex differences in the blood plasma zinc content.

The copper content in the blood plasma was found to be in average $16.92 \mu \mathrm{mol} / 1$, this value being similar to that reported by Jelínek, Illek and Jagoš (1982) and Krchňavý (1977) who, however, observed even higher variation of individual values. The copper content in blood plasma is markedly influenced by the level of copper intake in food. With deficient nutrition the copper content in blood plas- 
ma rapidly decreases, this fact being used in the diagnosis of copper deficiencies and metabolic disturbances (I1lek 1979). At copper deficiency the activity of ceruloplasmin was also observed to decrease. The copper deficiency unfavourably influences the pigment formation, growth, the quality of skin and hair and reproduction. The values found in healthy individuals may thus be regarded as physiological and they are applicable when comparing with the data obtained on the individual suffering from the reproduction disturbances, or changes in skin and hair quality.

\section{Metabolický profil krevní plazmy u dospělých samců nutrií (Myocastor coypus $\mathbf{M}_{\text {.) }}$}

V práci jsou uvedeny hodnoty základních biochemických ukazatelů (celková bílkovina, procentický podíl albuminu, globulinu alfa, globulinu beta a gama, urea, aktivita AST, ALT, alkalické fosfatázy, koncentrace glukózy, celkový vápník, anorganický fosfor, hořčík, mangan, zinek a měd') stanovené $v$ krevní plazmě 22 dospělých klinicky zdravých samců nutrií v průběhu letního období. Analyzovaná krev byla získávána srdeční punkcí.

\section{Мегаболический профиль кровяной плазмы у взрослых самцев нутрий (Myocastor coypus M.)}

В работе приведены величины основных биохимических показателей (общие белки, процентная доля альбумина, альфаглобулина, бета- и гамма-глобулина, мочевины, активность AST, ALT, щелочной фосьатазы, концентрация глюкозы, общий кальций, неорганический фосфор, магний, марганец, цинк и медь), определенные в кровяной плазме 22 взрослых клинически здоровых самцев нутрий в течение легнего периода. Анализируемая кровь была получена пункцией сердца.

\section{References}

BOYER, P. D. - SHAW, J. H. - PHILLIPS, P. H.: J. Biol. Chem., 143, 1942, 417. In: Underwood: Trace Elements in Human and Animal Nutrition 1977.

HENNIG, A.: Mineralstoffe, Vitamine, Ergotropika. VEB Deutsch. Landwirtschaftsverlag, Berlin, $1972,558 \mathrm{p}$.

HOŘEJŠI, J.: Základy klinické biochemie ve vnitřním lékařství. Praha, SZN, 1963, 576 p.

ILLEK, J.: Diagnostika karencí manganu, mědi a zinku u dojnic. Ph. D. Thesis, Brno, 1979, $182 \mathrm{p}$.

ILLEK, J. - JAGOŠ, P.: Obsah zinku, manganu a mědi v srsti a krevní plazmě dojnic. Referát přednesený na IX. Dnech fyziologie hospodářských zvířat. Liblice, 1977.

JAGOŠ, P.: Průzkum a vyhodnocení zdraví a veterinární prevence ve vybraných výkrmnách skotu. Project report, University of Veterinary Science Brno, 1975, 58 p.

JAGOŠ, P.: Základní biochemické a hematologické hodnoty u domácích zviřat a nové způsoby vyjadřování výsledkù laboratorních vyšetření. Veterinární péče ve velkochovech skotu, Pardubice, 1980 .

JELfNEK, P.: Studium některých hematologických a biochemických ukazatelů samců nutrií v průběhu postnatálního vývoje ve vztahu k činnosti pohlavních žláz. Habilitation Thesis, VŠZ Brno, 1980,295 p.

JELfNEK, P. - PfCHOVÁ, D. - PfCHA, J.: Hladiny plazmatického testosteronu u nutrií v průběhu postnatálního vývoje. Živ. výroba, Praha, 26, 1981: 225-234. 
JELINEK, P. - PfCHA, J. - PfCHOVÁ, D.: Koncentrace plazmatického tyroxinu $\left(\mathrm{T}_{4}\right)$ u samců nutrií od narození do období chovné dospèlosti. Acta univ. agric., Brno, 29, 1981: 289-295. JELINEK, P. - GLÁSROVÁ, M.: Cervený krevní obraz u samcủ nutrií v postnatálním období. Ved. Med., Praha, 27, 1982a: 227-235.

JELfNEK, P. - GLÁSROVÁ, M.: Bílý krevní obraz u samců nutrií v postnatálním období. Vet. Med., Praha, 27, 1982b: 337-348.

JELfNEK, P. - ILLEK, J. - JAGOŠ, P.: Obsah zinku, manganu a mědi v krevní plazmě, srsti, gonádách a př́idatných pohlavních žlázách nutrií. Živ. výr., Praha 27, 1982: 223-232.

KOLB, E. - GÜRTLER, H.: Ernährungsphysiologie der landwirtschaftlichen Nutztiere. Jena, VEB Gustav Fischer Verlag, 1971, 949 p.

KONRÁD, J.: Dílčí biochemická data krve nutrie. Unpublished data.

KONRÁD, J.: Choroby malých zviřat, I - nemoci králíků. SPN, Praha, 1973, 280 p.

KRCHÑAVY̌, J.: Stanovenie základných biochemických ukazatelov, makro- a mikroprvkov u klinicky zdravých nutrií. Studentská vědecká práce, Brno, 1977, 5 p.

SOVA, Z. - KOLIANDR, O. - JfCHA, J.: Základní fyziologické hodnoty v krvi ovcí. Sbor. Vys. šk. zeměd. Praha, fak. agron. řada $B, 1976: 57-71$.

SOVA, Z.: Soustava SI jednotek a její použivání v živočišné výrobě a veterinární medicíně. VSZZ Praha, 1979, 20 p.

SMITH, S. E. - MEDLICOTT, M. - ELLIS, G. H.: Arch. Biochem. 281, 4, 1944: (In: Underwood - Trace Element in Human and Animal Nutr. 1971).

UNDERWOOD, E. J.: Trace Elements in Human and Animal Nutrition. New York and London, Academic Press, 1971, 543 p.

VELIKÝ, I.: Mikroelementy $\mathrm{v}$ teórii a praxi. Bratislava, SVPL, 1964, $302 \mathrm{p}$.

WENZEL, U. D.: Edelpelztiere. Deutscher Landwirtschaftverlag, Berlin, 1974, 558 p.

WENZEL, U. D.: Pelztiergesundheitsdienst. Jena, VEB Gustav Fischer Verlag, 1982, 254 p.

WIESNER, E.: Fütterung und Fruchtbarkeit. Jena, VEB Gustav Fischer Verlag, 1972, 128 p. 